\title{
EFEKTIVITAS PELAKSANAAN MEDIASI DALAM PENYELESAAIN SENGKETA PERDATA DI PENGADILAN NEGERI BATAM
}

\author{
Sugito* \\ CV Masryan Karya Sukses
}

\begin{abstract}
To meet the needs of conducting Mediation that is more powerful and able to increase the success of Mediation in the Court so as to reduce the accumulation of cases in the court.Generally, the type of research used in this study is sociological (empirical) research methods. Based on the theory of legal effectiveness, there are 5 factors that influence the legal factor which are the law itself, law enforcement, facilities or facilities, community factors, and cultural factors. The conclusions of the research results that have been done through interviews and direct observations in the Batam District Court is the implementation of the mediation process in the Batam District Court has not been effective.
\end{abstract}

Keywords: Effectiveness, Implementing Mediation and Civil Disputes.

\begin{abstract}
Abstrak
Untuk memenuhi kebutuhan pelaksanaan Mediasi yang lebih berdayaguna dan mampu meningkatkan keberhasilan Mediasi di Pengadilan sehingga dapat mengurangi penumpukan perkara di pengadilan. Secara umum jenis penelitian yang digunakan dalam penelitian ini adalah penelitian berupa metode penelitian Sosiologis (empiris). Berdasarkan teori efektivitas hukum yang terdapat 5 Faktor-faktor yang mempengaruhi Faktor Hukum Itu Sendiri, Penegak Hukum, Faktor Sarana Atau Fasilitas, Faktor Masyarakat, dan Faktor Kebudayaan. Adapun kesimpulan Dari hasil penelitian yang telah dilakukan melalui wawancara dan pengamatan langsung di Pengadilan Negeri Batam, maka diperoleh kesimpulan dalam penelitian ini yaitu Pelaksanaan proses Mediasi di Pengadilan Negeri Batam belum berjalan efektif.
\end{abstract}

Kata Kunci: Efektivitas, Pelaksana Mediasi dan Sengketa Perdata.

\section{A. Latar Belakang Masalah}

Pada hari sidang yang telah ditetapkan pada pihak hadir dalam persidangan maka Majelis hakim wajib mendamaikan mereka yang bersengketa sebagaimana telah diatur dalam pasal 130 HIR/154 RBG. ${ }^{1}$ Dalam sengketa perdata di pengadilan umum, Mediasi wajib terlebih dahulu diupayakan sebelum memasuki ke tahap pemeriksaan pokok perkara, mediasi merupakan cara penyelesaian sengketa secara damai yang tepat, efektif dan dapat membuka akses yang lebih luas kepada Para Pihak untuk memperoleh penyelesaian yang

\footnotetext{
* Alamat Korespondensi : sugito88_ng@yahoo.com

${ }^{1}$ Maskur Hidayat, Strategi \& Taktik Mediasi Berdasarkan Perma No. 1 Tahun 2016 Tentang Prosedur Mediasi Di Pengadilan, Jakarta: Kencana, 2016, hlm 39.
} 
memuaskan serta berkeadilan, serta implementasi asas penyelenggaraan peradilan yang sederhana, cepat, dan berbiaya ringan. ${ }^{2}$

Pada tanggal 3 Februari Mahkamah Agung menerbitkan PERMA nomor 1 tahun 2016 tentang Prosedur Mediasi di Pengadilan, dengan mencabut PERMA Nomor 1 tahun 2008 tentang Prosedur Mediasi karena dianggap belum optimal dan efektif memenuhi kebutuhan pelaksanaan Mediasi yang lebih berdayaguna dan mampu meningkatkan keberhasilan Mediasi di Pengadilan sehingga dapat mengurangi penumpukan perkara di pengadilan baik di tingkat judex Factie maupun Mahkamah Agung.

Dengan berbagai alasan dan tujuan tersebut, selanjutnya muncul suatu pertanyaan yang mendasar adalah PERMA No. 1 Tahun 2016 tentang prosedur mediasi di Pengadilan apakah telah berjalan secara efektif dalam pelaksananya, dalam arti mampu mencapai target dan tujuannya dan asas peradilan sederhana, cepat dan biaya ringan kalaupun bisa, dengan alat ukur apa untuk menilai keefektifan proses mediasi di Pengadilan tersebut? dari permasalahan tersebut kiranya perlu ada pengkajian akademik secara mendalam untuk bisa mengetahui kekurangan dan kelebihan proses-proses mediasi tersebut, terlebih lagi untuk melakukan pembenahan apabila ditemukan beberapa permasalahan.

Dalam penelitian ini diperoleh data selama dari Tahun 2016 sampai dengan Tahun 2018, bebagai macam kasus sengketa perdata yang masuk di kepaniteraan berjumlah 962 perkara dan untuk perkara yang berhasil didamaikan melalui proses mediasi berjumlah 31 perkara. ${ }^{3}$ Berdasarkan data-data yang telah diuraikan diatas dapat disimpulkan bahwa mediasi sebagai instrumen dalam penyelesaian sengketa Perdata di Pengadilan Negeri Batam masih belum efektif.

Adapun tujuan dari penelitian ini adalah untuk Menganalisis dan menemukan efektivitas pelaksanaan penyelesaian sengketa perkara perdata melalui proses mediasi berdasarkan PERMA No. 1 Tahun 2016 di Pengadilan Negeri Batam, Menganalisis dan menemukan kekuatan mengikat PERMA No. 1 Tahun 2016 penyelesaian sengketa perkara perdata melalui proses mediasi di Pengadilan Negeri Batam. Dan serta untuk Menganalisis dan menemukan faktor-faktor dan hambatan apa dalam pelaksanaan proses mediasi di Pengadilan Negeri Batam.

\section{B. Rumusan Masalah}

1. Bagaimana efektivitas pelaksanaan penyelesaian sengketa perkara perdata melalui proses mediasi berdasarkan PERMA No. 1 Tahun 2016 di Pengadilan Negeri Batam?

2. Bagaimana kekuatan mengikat PERMA No. 1 Tahun 2016 dalam penyelesaian sengketa perkara perdata melalui proses mediasi di Pengadilan Negeri Batam?

3. Apa faktor-faktor dan hambatan dalam pelaksanaan proses mediasi di Pengadilan Negeri Batam?

\footnotetext{
${ }^{2}$ Peraturan Mahkamah Agung Nomor 1 Tahun 2016 tentang Prosedur Mediasi Di Pengadilan
}

${ }^{3}$ Rekapitulasi perkara gugatan yang masuk dari tahun 2016 sampai dengan Tahun 2018. 


\section{Metode Penelitian}

Jenis penelitian ini, Penulis menggunakan metode penelitian berupa metode penelitian empiris. Penelitian hukum empiris adalah suatu metode penelitian hukum yang berfungsi untuk melihat hukum dalam artian nyata dan meneliti bagaimana bekerjanya hukum di lingkungan masyarakat.

Dikarenakan dalam penelitian ini meneliti orang dalam hubungan hidup di masyarakat maka metode penelitian hukum empiris dapat dikatakan sebagai penelitian hukum sosiologis. Dapat dikatakan bahwa penelitian hukum yang diambil dari fakta-fakta yang ada di dalam suatu masyarakat, badan hukum atau badan pemerintah. ${ }^{4}$

Objek dalam penelitian ini adalah pelaksanaan mediasi dalam perkara sengketa perdata di Pengadilan Negeri Batam, objek penelitian tersebut di kaji berdasarkan Peraturan Mahkamah Agung Nomor 1 Tahun 2016 Tentang Prosedur Mediasi Di Pengadilan.

Teknik pengumpulan data penelitian hukum Empiris terdiri atas data primer dan skunder. Teknik pengumpulan data memiliki banyak cara dan dimana-mana, akan tetapi yang digunakan Penulis dalam penelitian ini dengan mengunakan studi keperpustakaan dengan menggunakan data sekunder dan data primer. ${ }^{5}$

Dalam penelitian ini metode-metode analisis data yang dipergunakan oleh Penulis adalah metode penelitian berupa metode penelitian deskriptif kualitatif. Landasan teori dimanfaatkan sebagai pemandu agar fokus penelitian sesuai dengan fakta di lapangan. Proses analisis data dalam penelitian kualitatif dimulai menelaah seluruh data yang terkumpul dari berbagai sumber, yaitu dari wawancara, pengamatan yang sudah dituliskan dalam catatan pada saat dilapangan, dokumen pribadi, dokumen resmi, gambar, foto dan sebagainya. ${ }^{6}$

Data-data yang diperoleh Penulis dari hasil studi kepustakaan akan diuraikan dalam pemaparan yang sistemik dan logis dengan memperhatikan dasardasar hukum yang telah ada beserta teori-teori yang secara tegas digunakan dalam penelitian ini.

Dalam penelitian ini, Penulis menggunakan analisis data dengan menggunakan pendekatan yang ditinjau dari perspektif peraturan perundangundangan yakni Peraturan Mahkamah Agung nomor 1 Tahun 2016 dan Wawancara berserta pengamatan langsung di Pengadilan Negeri Batam Kelas 1A.

\section{Hasil Penelitian Dan Pembahasan}

1. Efektivitas Pelaksanaan Penyelesaian Sengketa Perdata Melalui Proses Mediasi Berdasarkan PERMA Nomor 1 Tahun 2016 Di Pengadilan Negeri Batam.

\footnotetext{
${ }^{4}$ https://idtesis.com/metode-penelitian-hukum-empiris-dan-normatif/ diunduh tanggal 23 Maret 2019.

${ }^{5}$ Sugiyono, Metode Penelitian Kuantitatif Kualitatif Dan R \& D, Bandung: Alfabeta, 2013, hlm. 145.

${ }^{6}$ Syahruddin Nawi, Penelitian Hukum Normatif Versus Penelitian Hukum Empiris, Makasar: Umitoha, 2018, hlm. 53.
} 
Dari hasil penelitian yang telah dilakukan pada Pengadilan Negeri Batam Klas IA maka penulis memperoleh data dan informasi mengenai Laporan Rekapitulasi perkara gugatan yang masuk dari tahun 2016 sampai dengan Tahun 2018. Berikut gambaran dan Laporan Rekapitulasi perkara gugatan yang diterima Pengadilan Negeri Batam pada Tahun 2016.

\section{REKAPITULASI PERKARA GUGATAN PENGADILAN NEGERI BATAM TAHUN 2016.}

\begin{tabular}{|c|c|c|c|c|c|c|}
\hline Nomor & Bulan & $\begin{array}{c}\text { Perkara } \\
\text { Masuk }\end{array}$ & $\begin{array}{c}\text { Mediasi } \\
\text { Berhasil }\end{array}$ & $\begin{array}{c}\text { Mediasi } \\
\text { Gagal }\end{array}$ & $\begin{array}{c}\text { Cabut } \\
\text { Gugatan }\end{array}$ & Putusan \\
\hline 1 & Januari & 14 & 1 & 9 & 4 & 48 \\
\hline 2 & Februari & 26 & 1 & 17 & 2 & 48 \\
\hline 3 & Maret & 31 & 1 & 13 & 8 & 49 \\
\hline 4 & April & 28 & 2 & 9 & 2 & 56 \\
\hline 5 & Mei & 35 & 1 & 15 & 1 & 64 \\
\hline 6 & Juni & 31 & 2 & 11 & 4 & 79 \\
\hline 7 & Juli & 13 & & 19 & 1 & 75 \\
\hline 8 & Agustus & 29 & 1 & 15 & 2 & 69 \\
\hline 9 & September & 24 & & 14 & 5 & 87 \\
\hline 10 & Oktober & 35 & 2 & 13 & 2 & 95 \\
\hline 11 & November & 21 & 1 & 9 & 2 & 99 \\
\hline 12 & Desember & 18 & 1 & 6 & 2 & 108 \\
\hline Total & & $\mathbf{3 0 5}$ & $\mathbf{1 3}$ & $\mathbf{1 5 0}$ & $\mathbf{3 9}$ & $\mathbf{8 7 7}$ \\
\hline
\end{tabular}

Sumber Data Kepaniteraan Pengadilan Negeri Batam Tahun 2016

Dari tabel diatas perkara gugatan yang masuk pada Bulan Januari sampai dengan Bulan Desember Tahun 2016 berjumlah 305 perkara. Untuk perkara yang dinyatakan berhasil dalam proses mediasi berjumlah 13 perkara. Dengan melihat rekapitulasi laporan mediasi ini dapat disimpulkan, bahwa di Pengadilan Negeri Batam Klas IA masih minim sekali Proses mediasi yang tercapai kebehasilan.

\section{REKAPITULASI PERKARA GUGATAN PENGADILAN NEGERI BATAM TAHUN 2017.}

TABEL 2

\begin{tabular}{|c|c|c|c|c|c|c|}
\hline Nomor & Bulan & $\begin{array}{c}\text { Perkara } \\
\text { Masuk }\end{array}$ & $\begin{array}{c}\text { Mediasi } \\
\text { Berhasil }\end{array}$ & $\begin{array}{c}\text { Mediasi } \\
\text { Gagal }\end{array}$ & $\begin{array}{c}\text { Cabut } \\
\text { Gugatan }\end{array}$ & Putusan \\
\hline 1 & Januari & 20 & 1 & 6 & 2 & 124 \\
\hline
\end{tabular}




\begin{tabular}{|c|l|c|c|c|c|c|}
\hline 2 & Februari & 19 & 1 & 10 & 1 & 114 \\
\hline 3 & Maret & 27 & 1 & 10 & 3 & 124 \\
\hline 4 & April & 27 & & 8 & 2 & 139 \\
\hline 5 & Mei & 43 & 2 & 12 & 4 & 170 \\
\hline 6 & Juni & 13 & 1 & 9 & 0 & 169 \\
\hline 7 & Juli & 29 & & 11 & 9 & 192 \\
\hline 8 & Agustus & 32 & & 22 & 5 & 206 \\
\hline 9 & September & 24 & 1 & 9 & 4 & 187 \\
\hline 10 & Oktober & 26 & & 16 & 3 & 98 \\
\hline 11 & November & 43 & 1 & 12 & 5 & 78 \\
\hline 12 & Desember & 24 & 2 & 8 & 1 & 56 \\
\hline Total & & $\mathbf{3 2 7}$ & $\mathbf{1 0}$ & $\mathbf{1 3 3}$ & $\mathbf{3 9}$ & $\mathbf{1 , 6 5 7}$ \\
\hline
\end{tabular}

Sumber Data Kepaniteraan Pengadilan Negeri Batam Tahun 2017

Dari tabel diatas perkara gugatan yang masuk pada Bulan Januari sampai dengan Bulan Desember Tahun 2017 berjumlah 327 perkara. Untuk perkara yang dinyatakan berhasil mediasi berjumlah 10 perkara. Dengan melihat rekapitulasi laporan mediasi ini dapat disimpulkan, bahwa di Pengadilan Negeri Batam Klas IA masih minim sekali proses mediasi yang tercapai kebehasilan.

\section{REKAPITULASI PERKARA GUGATAN PENGADILAN NEGERI BATAM TAHUN 2018.}

TABEL 3

\begin{tabular}{|c|c|c|c|c|c|c|}
\hline Nomor & Bulan & $\begin{array}{c}\text { Perkara } \\
\text { Masuk }\end{array}$ & $\begin{array}{c}\text { Mediasi } \\
\text { Berhasil }\end{array}$ & $\begin{array}{c}\text { Mediasi } \\
\text { Gagal }\end{array}$ & $\begin{array}{c}\text { Cabut } \\
\text { Gugatan }\end{array}$ & Putusan \\
\hline 1 & Januari & 27 & 2 & 17 & 0 & 70 \\
\hline 2 & Februari & 26 & 1 & 2 & 2 & 79 \\
\hline 3 & Maret & 36 & & 16 & 4 & 72 \\
\hline 4 & April & 26 & & 11 & 1 & 76 \\
\hline 5 & Mei & 36 & 2 & 20 & 2 & 90 \\
\hline 6 & Juni & 20 & & 4 & 0 & 92 \\
\hline 7 & Juli & 22 & & 12 & 3 & 107 \\
\hline 8 & Agustus & 31 & 2 & 9 & 0 & 103 \\
\hline 9 & September & 26 & 1 & 7 & 0 & 89 \\
\hline 10 & Oktober & 30 & & 10 & 3 & 74 \\
\hline 11 & November & 24 & & 11 & 0 & 56 \\
\hline 12 & Desember & 26 & & 7 & 1 & 33 \\
\hline Total & & $\mathbf{3 3 0}$ & $\mathbf{8}$ & $\mathbf{1 2 6}$ & $\mathbf{1 6}$ & $\mathbf{9 4 1}$ \\
\hline
\end{tabular}

Sumber Data Kepaniteraan Pengadilan Negeri Batam Tahun 2018

Dari tabel 3 diatas perkara gugatan yang masuk pada Bulan Januari sampai dengan Bulan Desember Tahun 2018 berjumlah 330 perkara. Untuk perkara yang dinyatakan berhasil tercapai perdamaian berjumlah 8 perkara. Dengan melihat rekapitulasi laporan mediasi ini dapat disimpulkan, bahwa di 
Pengadilan Negeri Batam Klas IA masih minim sekali proses mediasi yang tercapai kebehasilan.

Merujuk pada tabel tersebut di atas dari Tahun 2016 sampai dengan Tahun 2018, perkara yang masuk di kepaniteraan berjumlah 962 perkara dan untuk perkara yang berhasil didamaikan melalui proses mediasi berjumlah 31 perkara.

Berdasarkan data-data yang telah diurai di atas dapat disimpulkan bahwa mediasi sebagai instrumen dalam penyelesaian sengketa Perdata di Pengadilan Negeri Batam masih belum efektif.

Untuk hal ini salah seorang hakim mediator pada Pengadilan Negeri Batam menerangkan bahwa apabila efektivitas mediasi diukur dari keberhasilan mendamaikan para pihak masih jauh dari harapan masih minimalisir, dan untuk perkara yang harus diputus masih terjadi penumpukan perkara maka dapat dikatakan bahwa mediasi dalam sengketa perkara perdata di Pengadilan Negeri Batam secara umum masih belum efektif. ${ }^{7}$

Dengan data-data dan informasi yang diperoleh dan hasil wawancara oleh penulis dan juga pengamatan lansung yang dilakukan oleh penulis sedemikian rupa sehingga penulis menyimpulkan pelaksanaan mediasi di Pengadilan Negeri Batam masih belum efektif. Disini dapat kita lihat masih terdapat banyak perkara yang (deadlock) atau gagal dimediasi serta adanya penumpukan perkara atau perkara masih dalam proses menuju ke putusan.

Berdasarkan data maupun informasi di lapangan yang oleh Penulis didapatkan dalam penelitian ini dan untuk mengertahui faktor-faktor yang mana saja mempengaruhi Proses Mediasi dalam Penyelesaian Sengketa Perdata di Pengadilan Negeri Batam yang belum efektif.

Maka dengan ini penulis menggunakan teknis analisis data kualitatif Berdasarkan teori efektivitas hukum yang dikemukakan Soerjono Soekanto, efektif atau tidaknya suatu hukum ditentukan oleh 5 (lima) Faktor yang pertama adalah Faktor hukumnya sendiri, kedua adalah faktor penegak hukum, Yang ketiga adalah faktor sarana atau fasilitas, Keempat adalah Faktor masyarakat dan yang kelima faktor kebudayaan. ${ }^{8}$

Kelima faktor yang tersebut diatas akan dijadikan pengacuan atau sebagai alat ukur penelitian ini dan berikut adalah penguraian mengenai analisa Efektivitas Pelaksanaan penyelesaian sengketa perdata melalui proses mediasi berdasarkan PERMA No. 1 Tahun 2016 di Pengadilan Negeri Batam :

\footnotetext{
${ }^{7}$ Wawancara Dengan Jasael, Hakim Mediator Pengadilan Negeri Batam Pada Tanggal 12 Februari 2019.

${ }^{8}$ Soerjono Soekanto, Faktor-Faktor yang Mempengaruhi Penegak Hukum, Cetakan Ke13, Jakarta: PT. Rajagrafindo Persada, 2014, hlm. 8.
} 
Salah seorang Mediator juga menambahkan dari pengaturan PERMA No. 1 Tahun 2016 cukup baik dan lengkap karena ada beberapa hal baru yang diatur misalnya jangka waktu penyelesaian mediasi lebih singkat dari 40 hari menjadi 30 hari terhitung penertapan mediator. Kedua, kewajiban para pihak menghadiri pertemuan mediasi dengan atau tanpa kuasa hukum, kecuali ada alasan sah dalam hal ini principal langsung diharapkan berperan aktif dalam proses mediasi. Hal terpenting adanya itikad baik dan akibat hukum (sanksi) para pihak yang tidak beritikad baik dalam proses mediasi. ${ }^{9}$

Dari hasil wawancara dan hasil pengamatan langsung oleh penulis di Pengadilan Negeri Batam dapat disimpulkan bahwa dari Faktor Hukum Itu Sendiri untuk pelaksanaan proses mediasi di Pengadilan Negeri Batam sudah cukup efektif.

\section{Faktor Penegak Hukum}

Pengak hukum yang dapat menentukan Efektif atau tidaknya kinerja hukum tertulis, aparat penegak hukum dalam hubungan ini dikehendaki adanya aparatur yang handal sehingga aparat tersebut dapat melakukan tugasnya dengan baik.

Dalam penelitian ini penegak hukum yakni pihak yang menerapkan hukum proses mediasi di Pengadilan Negeri Batam Klas IA yaitu:

\section{Hakim memeriksa perkara sengketa perdata.}

Berdasarkan hasil wawancara dari salah seorang hakim yang pernah menjadi ketua majelis hakim maupun hakim anggota menerangkan dari penegak hukumnya yaitu majelis hakim yang memeriksa perkara, dalam melaksanakan proses mediasi sudah cukup baik tidak pernah terjadi penyimpangan, sesuai amanah perma no. 1 tahun 2016 karena dalam pemeriksaan perkara Mediasi selalu diupayakan terlebih dahulu karena hal ini sesuai dengan hal yang terkandung dan diatur berdasarkan PERMA nomor 1 Tahun 2016 tentang prosedur mediasi. Mendorong Para Pihak untuk menempuh proses perdamaian, dan juga diatur Pasal 154 Reglemen Hukum Acara untuk Daerah Luar Jawa dan Madura (Reglement Tot Regeling an Het Rechtswezen In De Gewesten Buiten Java En Madura) dan Pasal 130 Reglemen Indonesia yang diperbaharui (Het Herziene Indonesisch Reglement, Staatsblad 1941:44) mendorong Para Pihak untuk menempuh proses perdamaian untuk mengakhiri perkara yang disengketakan. ${ }^{10}$

Dalam hal ini penulis juga melakukan wawancara dengan salah seorang advokat yang menerangkan untuk proses mediasi peran majelis hakim dalam melaksanakan perma ini sudah cukup baik, dan sudah dilaksanakan sebagaimana mestinya dalam berperkara di Pengadilan Negeri Batam pada hari sidang pertama dan dihadiri oleh para pihak majelis hakim selalu memcoba mendamaikan para pihak yang bersengketa dan menjelaskan kepada Para Pihak untuk menempuh proses Mediasi terlebih dahulu sesuai perma no. 1 tahun 2016 dan mejelis hakim

\footnotetext{
${ }^{9}$ Wawancara Dengan Muhammad Candra, Hakim Mediator Pengadilan Negeri Batam Pada Tanggal 12 Februari 2019.

${ }^{10}$ Wawancara Dengan Jasael, Hakim Mediator Pengadilan Negeri Batam Pada Tanggal 12 Februari 2019.
} 
akan menunggu laporan hasil mediasi dari hakim mediator, berhasil atau ketidakberhasilan mediasi dan/atau tidak dapat dilaksanakannya Mediasi. ${ }^{11}$

\section{Hakim Mediator}

Mediator adalah Hakim atau pihak lain yang memiliki Sertifikat Mediator sebagai pihak netral yang membantu Para Pihak dalam proses perundingan guna mencari berbagai kemungkinan penyelesaian sengketa tanpa menggunakan cara memutus atau memaksakan sebuah penyelesaian. ${ }^{12}$

Berdasarkan hasil wawancara dari salah seorang hakim mediator menerangkan yang dapat menjadi mediator adalah seseorang yang memiliki Sertifikat Mediator yang diperoleh setelah mengikuti dan dinyatakan lulus dalam pelatihan sertifikasi Mediator yang diselenggarakan oleh Mahkamah Agung atau lembaga yang telah memperoleh akreditasi dari Mahkamah Agung.

Dan juga bisa Berdasarkan surat keputusan ketua Pengadilan, Hakim tidak bersertifikat dapat menjalankan fungsi Mediator dalam hal tidak ada atau terdapat keterbatasan jumlah Mediator bersertifikat. ${ }^{13}$

Berdasarkan uraian diatas maka yang dapat bertindak sebagai mediator adalah Hakim atau pihak lain, maksud pihak lain disini baik itu dari mediator pengacara maupun mediator swasta yang mempunyai sertifikat mediator untuk hakim yang tidak bersertifikat mediator dapat bertidak sebagai hakim mediator berdasarkan surat keputusan ketua Pengadilan.

Dalam praktek di Pengadilan pada saat penentuan mediator para pihak yang bersengketa selalu memilih mediator dari hakim Pengadilan tersebut untuk bertindak sebagai hakim mediator dan disisi lain mediator dari hakim Pengadilan tidak perlu biaya, oleh sebab inilah dalam praktek di Pengadilan Negeri Batam Para Pihak yang bersengketa rata-rata memilih Mediator Hakim yang terdaftar di Pengadilan Batam.

Hal yang sama juga diterang oleh salah seorang mediator Pengadilan Negeri Batam yang menerangkan sesuai pengalaman saya sebagai hakim maupun hakim mediator dalam sengketa di pengadilan negeri Batam mediator yang dipilih para pihak untuk menbantu para pihak untuk melaksanakan mediasi semua dari mediator hakim, selama ini belum pernah para pihak memilih mediator swasta karena faktor biaya yang mahal sedangkan mediator hakim dari pengadilan tanpa biaya atau gratis.

Berdasarkan hasil wawancara dari salah seorang hakim mediator menerangkan dalam pelaksanaan proses mediasi, dari hakim mediator telah menjalankan sesuai apa yang telah ditentukan dalam perma no. 1 tahun 2016.

Dalam awal pertemuan mediasi dan para pihak lengkap atau hadir dalam mediasi hakim mediator memperkenalkan diri dan memberi kesempatan kepada

\footnotetext{
${ }^{11}$ Wawancara Dengan Rudianto Di Pengadilan Negeri Batam Pada Tanggal 14 Mei 2019.

12 Peraturan Mahkamah Agung Nomor 1 Tahun 2016 Tentang Prosedur Mediasi Di Pengadilan, Pasal 1 Angka (2).

${ }^{13}$ Wawancara dengan Jasael, Hakim Mediator Pengadilan Negeri Batam Pada Tanggal 12 Februari 2019.
} 
Para Pihak untuk saling memperkenalkan diri, menjelaskan maksud, tujuan mediasi untuk mencari titik temu mendapat hasil yang win-win solution, menjelaskan kedudukan dan peran Mediator yang netral dan tidak punya kepentingan, menyusun jadwal Mediasi bersama Para Pihak; mengisi formulir jadwal mediasi. Memberikan kesempatan kepada Para Pihak untuk menyampaikan permasalahan dan usulan perdamaian. ${ }^{14}$

Pengamatan langsung oleh penulis pada tanggal 7 Desember 2018 proses mediasi perkara Nomor 277/Pdt. G/2018/Pn. Btm dalam perkara ini yang menjadi mediator adalah Hakim mediator dari Pengadilan Negeri yang bernama Jasael, S.H., M.H. yang ditunjuk oleh majelis hakim yang memeriksa perkara ini sebagai mediator untuk menbantu para pihak yang berperkara untuk menempuh proses mediasi.

Pada pertemuan pertama ini mediator juga mendorong para pihak untuk berpikir tentang sengketa dari berbagai segi. Mediator juga menasehati para pihak, memberikan arahan dan solusi serta menjelaskan jika sengketa bisa diselesaikan dengan damai maka tidak ada pihak yang kalah atau menang, berdamai merupakan hal yang indah, tapi jika sengketa berlanjut ke proses litigasi berarti ada yang kalah dan ada yang menang.

Dalam Mediasi ini baik pihak penggugat maupun pihak tergugat saling tertutup susah diajak berunding tetap saja mereka tidak mau atau susah diajak mencari jalan keluar dari permasalahan yang mereka hadapi dan dari mediator sendiri juga sudah berusaha untuk mengarahkan untuk berdamai namun gagal.

Dari mediator mengarahkan untuk melakukan mediasi lanjutan namun dari pihak penggugat keberatan karena pihak penggugat harus berangkat ke bali untuk bekerja dan pihak Penggugat juga memberikan usulan opsi yang tidak mau untuk berdamai, mediator melihat tidak ada perkembangan kearah perdamaian atau titik terang, dan juga mempertimbangkan untuk pertemuan mediasi lanjutan tidak mungkin terlaksana sehingga mediasi harus dinyatakan gagal (dead lock).

Hal yang senada juga disampaikan oleh salah seorang Advokat yang mendampingi penggugat dalam proses mediasi ini menyatakan dalam melaksanakan proses mediasi peran mediator dalam menjalankan tugas sudah professional dan baik, untuk berhasil atau gagalnya mediasi merupakan faktor dari para pihak itu sendiri. Mediator hanya bisa mencari berbagai kemungkinan penyelesaian sengketa memberikan solusi dan arahan tanpa menggunakan cara memutus atau memaksakan sebuah penyelesaian. ${ }^{15}$

Dari hasil wawancara dan hasil pengamatan langsung oleh penulis di Pengadilan Negeri Batam dapat disimpulkan bahwa dari Faktor Penegak hukum untuk pelaksanaan proses mediasi di Pengadilan Negeri Batam sudah cukup efektif.

\section{Faktor Sarana Atau Fasilitas}

Tanpa adanya sarana dan fasilitas tertentu, maka tidak mungkin penegak hukum akan berlangsung dengan lancar, sarana atau fasilitas tersebut, antara lain,

\footnotetext{
${ }^{14}$ Wawancara Dengan Muhammad Candra, Hakim Mediator Pengadilan Negeri Batam Pada Tanggal 12 Februari 2019.

${ }^{15}$ Wawancara dengan Rudianto Di Pengadilan Negeri Batam Pada Tanggal 14 Mei 2019.
} 
mencangkup tenaga manusia, organisasi yang baik, peralatan yang memadai, keuangan yang cukup, dan seterusnya. Kalau hal-hal itu tidak terpenuhi, maka mustahil penegak hukum akan mencapai tujuannya. ${ }^{16}$

\section{Ruangan Mediasi Di Pengadilan Negeri Batam Merupakan Sarana Atau} Fasilitas Dalam Penelitian Ini.

Menurut salah seorang Panitera Muda Hukum menerangkan ruang mediasi di Pengadilan Negeri Batam hanya ada 1 (satu) ruangan dan cukup sempit yang berukuran kurang lebih sekitar 2,8 meter x 5,8 meter, di dalamnya hanya ada 1 meja panjang dan 6 kursi, sebuah papan tulis kecil dan sebuah Penyejuk Udara atau $\mathrm{AC}$ (air conditioner). ${ }^{17}$

Berdasarkan Hasil Wawancara salah seorang hakim mediator menerangkan untuk ruang mediasi dengan pendekatan psikologis dan dari hati ke hati, mediator mencoba mendamaikan para pihak yang bersengketa. Oleh karena itu, jangan sepelekan peran ruang mediasi. Selain ditentukan hasil akhirnya oleh hakim sebagai mediator dan kedua pihak, ruang mediasi memiliki peran yang tak kalah pentingnya.

Dalam hal ini Ruang mediasi hanya ada 1 (satu) dan juga masih kurang memadai, masih jauh dari harapan dan masih kurang ideal bagi proses mediasi. Faktor-faktor yang menyebabkan tidak idealnya ruang mediasi adalah sebagai berikut:

a. Ruang yang sempit sehingga membuat tidak nyaman para pihak dan mediator sendiri.

b. Ruangan mediasi hanya satu sehingga terkadang untuk melaksanakan proses mediasi harus menunggu ruagan mediasi tidak ada yang mengunakan baru dapat melaksanakan mediasi. ${ }^{18}$

Dalam hal ini Penulis melakukan wawancara dengan beberapa orang Pengacara atau Advokat yang sering beracara di Pengadilan Negeri Batam menerangakan sebagai berikut :

Ruangan mediasi yang tersedia hanya ada 1 (satu) ruangan saja sedangkan perkara yang masuk di Pengadilan Negeri Batam cukup banyak sehingga tidak sebanding dengan perkara yang akan di mediasikan kalau hanya satu ruangan saja tidak sesuai sehingga muncul keadaan para pihak seringkali terlihat mengantri. ${ }^{19}$

Untuk ruangan masih terlalu sempit sehingga kalau ada perkara yang para pihaknya terlalu banyak maka harus menambah kursi dan duduknya terlalu berdempet untuk kenyamanan menjadi berkurang. ${ }^{20}$

Untuk Penyejuk udara atau AC (air conditioner) dalam ruangan mediasi masih kurang dingin sehingga saat melakukan mediasi kondisi ruangan masih

\footnotetext{
${ }^{16}$ Soerjono Soekanto, Sri Mamudji, Penelitian Hukum Normatif Suatu Tinjauan Singkat, Cetakan ke-17, Jakarta: Rajawali Pers, 2015, hlm. 37.

${ }^{17}$ Wawancara dengan Netty Sihombing, Tanggal 18 Maret 2019 di Pengadilan Negeri Batam.

18 Wawancara dengan Jasael, Hakim Mediator Pengadilan Negeri Batam Pada Tanggal 12 Februari 2019.

${ }^{19}$ Wawancara dengan Rudianto, tanggal 12 Maret 2019 di Pengadilan Negeri Batam.

${ }^{20}$ Wawancara dengan Yohanes Harry, tanggal 12 Maret 2019 di Pengadilan Negeri Batam.
} 
terasa panas sehingga membuat kondisi kurang nyaman saat melaksanakan mediasi. ${ }^{21}$

Dari hasil wawancara dan hasil pengamatan langsung oleh penulis di Pengadilan Negeri Batam dapat disimpulkan bahwa untuk sarana dan fasilitas untuk pelaksanaan mediasi di Pengadilan Negeri Batam masih belum efektif.

\section{Faktor Masyarakat}

Faktor masyarakat, yakni lingkungan dimana hukum itu berlaku atau diterapkan, Faktor masyarakat dalam hal ini penulis menganggap para pihak yang berpekara di pengadilan negeri batam adalah bagian dari faktor masyarakat dalam penelitian ini.

Mengenai faktor masyarakat, penulis dalam pengamatan langsung dari beberapa perkara dan juga berdasarkan infomasi memberikan catatan mengenai perilaku dan sikap para pihak selama proses mediasi yang mempengaruhi ketidakberhasilan dalam menjalani proses mediasi, yakni sebagai berikut:

a. Seringkali salah satu pihak atau keduanya merasa paling benar sehingga Mediator kesulitan mendalami masalah karena sikap mereka yang tidak kooperatif selama proses mediasi dan juga sikap egois sering muncul pula pada diri para pihak.

b. Sebelum para pihak memasuki pemeriksaan perkara di persidangan, sering kali mereka sudah pernah melakukan negosiasi sehingga saat dilakukan mediasi, sangat sulit bahkan gagal untuk didamaikan.

c. Konflik yang telah berlarut-larut lamanya menyebabkan kedua belah pihak sudah tidak ada itikad baik untuk damai.

d. Para pihak ada juga yang kooperatif, namun sikap tersebut mereka lakukan agar proses mediasi cepat selesai dapat dilanjutkan ke proses persidangan selanjutnya. Mereka mengikuti mediasi hanya sebagai formalitas dan memenuhi ketentuan hukum saja untuk penggugat supaya gugatan jangan sampai digugurkan.

e. Faktor gengsi para pihak yang tinggi terutama jika sudah menyangkut harta, laba rugi dan harga diri.

Hal-hal inilah yang menyebabkan mediasi gagal (dead lock) proses mediasi sulit untuk tercapai keberhasilan berdamai.

Menurut salah satu hakim mediator yang menerangkan mediasi berhasil atau tidak berhasil maupun tidak dapat dilaksanakan sangat tergatung pada adanya itikad baik para pihak untuk melakukan mediasi dan adanya niat yang sama antara para pihak mencapai perdamaian, intinya tergantung dari para pihak yang bersengketa itu sendiri. ${ }^{22}$

Menurut salah satu hakim mediator juga sependapat bahwa mediasi berhasil atau tidak berhasil maupun tidak dapat dilaksanakan sangat tergatung pada adanya itikad baik para pihak untuk melakukan mediasi dan adanya niat yang sama antara para pihak mencapai perdamaian, intinya tergantung dari para pihak yang bersengketa itu sendiri.

${ }^{21}$ Wawancara dengan Tatimin, Tanggal 12 Maret 2019 di Pengadilan Negeri Batam.

22 Wawancara Dengan Muhammad Candra, Hakim Mediator Pengadilan Negeri Batam Pada

Tanggal 12 Februari 2019. 
Dari hasil wawancara dan hasil pengamatan langsung oleh penulis di Pengadilan Negeri Batam dapat disimpulkan bahwa dari Faktor Masyarakat untuk pelaksanaan proses mediasi di Pengadilan Negeri Batam masih belum efektif.

\section{Faktor Kebudayaan.}

Budaya para pihak yang bersengketa di pengadilan negeri batam yang sama sekali tidak memperjuangkan budaya musyawarah secara rasional untuk bisa dipergunakan sebagai penyelesaian sengketa namun kebanyakan merasa pada perkara tersebut telah berlangsung lama dan juga sebelum menggugat di Pengadilan sudah pernah dicoba untuk diselesaikan secara kekeluargaan baik dengan mediasi dan juga negosiasi yang dilakukan dengan berulang kali, namun tidak menbuahkan hasil juga maka satu-satunya jalan adalah penyelesaian permasalahan mereka adalah melalui jalur litigasi merupakan jalur terakhir untuk mengakhiri sengketa.

Sehingga pada saat dilakukan proses mediasi di Pengadilan, para pihak terkesan kurang atau tidak ada kemauan sama sekali untuk bersungguh-sungguh mengupayakan perdamaian dan hanya menganggap proses mediasi merupakan formalitas untuk melanjutkan perkara ke proses selanjutnya. Hal ini yang ditemukan para beberapa kasus yang ditangani di pengadilan negeri batam. ${ }^{23}$

Dari uraian diatas maka dapat penulis tarik kesimpulan bahwa dari Faktor Kebudayaan untuk pelaksanaan proses mediasi di Pengadilan Negeri Batam masih belum efektif.

4.1.2. Kekuatan Mengikat PERMA Nomor 1 Tahun 2016 Dalam Penyelesaian Sengketa Perkara Perdata Melalui Proses Mediasi Di Pengadilan Negeri Batam.

Menurut Yahya Harahap, kekuasaan dan kewenangan lain yang dianggap berkaitan dengan pengawasan dan pembinaan Mahkamah Agung ialah membuat peraturan sebagai kebijakan pembinaan dan pengawasan internal.

Kekuasaan dan kewenangan itu ditegaskan pada angka 2 huruf c penjelasan umum Undang-Undang Mahkamah Agung, yang berbunyi: Membuat peraturan sebagai pelengkap untuk mengisi kekosongan hukum yang di perlukan bagi kelancaran jalannya peradilan.

Begitu pula dengan Pasal 79 Undang-undang Mahkamah Agung, memberi kewenangan kepada Mahkamah Agung mengatur lebih lanjut hal-hal yang diperlukan penyelenggaraan peradilan apabila terdapat hal-hal yang belum cukup diatur dalam undang-undang.

Lebih lanjut, penjelasan Pasal 79 tersebut menyatakan apabila jalannya peradilan terdapat kekurangan atau kekosongan hukum dalam suatu hal, maka Mahkamah Agung berwenang membuat peraturan sebagai pelengkap untuk mengisi kekosongan atau kekurangan itu. ${ }^{24}$

\footnotetext{
${ }^{23}$ Wawancara Dengan Jasael, Hakim Mediator Pengadilan Negeri Batam Pada Tanggal 12 Februari 2019.

${ }^{24}$ H.M. Fauzan, Peranan PERMA \& SEMA Sebagai Pengisi Kekosongan Hukum Indonesia Menuju Terwujudnya Peradilan Yang Agung, Jakarta: Kencana Prenadamedia Group, 2013, hlm. $\mathrm{x}-\mathrm{xi}$.
} 
Berdasarkan ketentuan Pasal 8 Ayat (1) Undang-undang No 12 Tahun 2011 tersebut, maka; Pertama, Peraturan Mahkamah Agung diakui keberadaannya sebagai jenis peraturan perundang-undangan dan pada Undang-undang Republik Indonesia Nomor 14 Tahun 1985 Tentang Mahkamah Agung juncto Undangundang Nomor 5 Tahun 2004 Tentang Perubahan atas Undang-undang Nomor 14 Tahun 1985 tentang Mahkamah Agung juncto Undang- undang Nomor 3 Tahun 2009 Tentang Perubahan Kedua atas Undang-undang Nomor 14 Tahun 1985 tentang Mahkamah Agung juga mengatur sebagai berikut:

\section{Pasal 79}

Mahkamah Agung dapat mengatur lebih lanjut hal-hal yang diperlukan bagi kelancaran penyelenggaraan peradilan apabila terdapat hal-hal yang belum cukup diatur dalam Undang-undang ini.

Dalam Penjelasan: Apabila dalam jalannya peradilan terdapat kekurangan atau kekosongan hukum dalam suatu hal, Mahkamah Agung berwenang membuat peraturan sebagai pelengkap untuk mengisi kekurangan atau kekosongan tadi. Dengan Undang-undang ini Mahkamah Agung berwenang menentukan pengaturan tentang cara penyelesaian suatu soal yang belum atau tidak diatur dalam Undangundang ini.

Dalam hal ini peraturan yang dikeluarkan oleh Mahkamah Agung dibedakan dengan peraturan yang disusun oleh pembentuk Undang-undang. penyelenggaraan peradilan yang dimaksudkan Undang-undang ini hanya merupakan bagian dari hukum acara secara keseluruhan.

Dengan demikian Mahkamah Agung tidak akan mencampuri dan melampaui pengaturan tentang hak dan kewajiban warga negara pada umumnya dan tidak pula mengatur sifat, kekuatan, alat pembuktian serta penilaiannya ataupun pembagian beban pembuktian.

Maka kedudukan PERMA sebagai jenis dari peraturan perundangundangan yang ditetapkan Mahkamah Agung diakui keberadannya dan mempunyai kekuatan hukum yang mengikat tidak hanya secara internal sepanjang peraturan di buat menyinggung lembaga negara lain diperlukan oleh Undang-undang yang lebih tinggi atau dibentuk berdasarkan kewenangan.

Berdasarkan hasil wawancara salah seorang Hakim mediator Pengadilan Negeri Batam menerangkan sesuai Undang-undang Mahkamah Agung pasal 79 Mahkamah Agung dapat mengatur lebih lanjut hal-hal yang diperlukan bagi kelancaran penyelenggaraan peradilan apabila terdapat hal-hal yang belum cukup diatur dalam Undang-undang ini.

Dalam Penjelasan: Apabila dalam jalannya peradilan terdapat kekurangan atau kekosongan hukum dalam suatu hal, Mahkamah Agung berwenang membuat peraturan sebagai pelengkap untuk mengisi kekurangan atau kekosongan tadi.

Dengan Undang-undang ini Mahkamah Agung berwenang menentukan pengaturan tentang cara penyelesaian suatu soal yang belum atau tidak diatur dalam Undang-undang ini.

\subsubsection{Faktor Faktor Dan Hambatan Dalam Pelaksanaan Proses Mediasi Di Pengadilan Negeri Batam.}


Dari hasil Wawancara pada salah seorang mediator Pengadilan Negeri Batam yang menerangkan faktor dan hambatan-hambatan dalam proses mediasi di Pengadilan Negeri Batam sebagai Berikut: ${ }^{25}$

\section{Keterbatasan Jumlah Mediator Yang Terdaftar Di Pengadilan Negeri} Batam.

Jumlah Mediator dan Jumlah Hakim yang Terbatas Hal ini mempengaruhi pula terhadap pelaksana mediasi di Pengadilan Negeri Batam.

Dari hasil wawancara dari salah seorang hakim mediator menerangkan jumlah Mediator dan jumlah Hakim yang terbatas, merupakan suatu hambatan dan hal ini mempengaruhi pula terhadap pelaksanaan mediasi di Pengadilan Negeri Batam. padahal jumlah perkara perdata yang diajukan ke Pengadilan terbilang banyak dari rekapitulasi tahun 2016 sampai 2018 rata-rata diatas tiga ratusan perkara dan memerlukan mediator.

Sampai saat ini jumlah mediator yang terdaftar di Pengadilan masih sangat sedikit, dan tidak sesuai dengan jumlah perkara yang masuk. Oleh karena itu, guna pemberdayaan PERMA tersebut, maka jumlah tenaga mediator harus ditingkatkan yang didukung pula oleh mediator swasta akan tetapi mediator swasta sangat jarang sekali dipilih oleh para yang bersengketa untuk menjadi mediator. ${ }^{26}$

mediator dari hakim dan mediator swasta berjumlah 19 orang, akan tetapi ada beberapa hakim Mediator sudah pindah tugas ke Pengadilan lain jadi mediator yang ada di Pengadilan Negeri Batam untuk saat hanya berjumlah 10 hakim mediator, Jadi masih terdapat adanya keterbatasan jumlah mediator dan juga untuk jumlah mediator yang ada apabila dibandingkan dengan perkara yang masuk di kepaniteraan tidak seimbang.

Sedangkan untuk mediator Swasta selama saya bertugas di Pengadilan Negeri Batam bertindak sebagai ketua majelis maupun hakim anggota dalam sengketa perdata para pihak yang bersengketa, belum saya ketemu para pihak memilih mediator dari non hakim ataupun swasta dan boleh dikatakan semua memakai hakim mediator dari Pengadilan. mungkin dikarenakan memilih mediator dari hakim pengadilan tanpa biaya atau gratis sedangkan untuk memilih mediator swasta mungkin terkendala pihak mana yang menangung biaya mediator swasta tersebut. Sehingga dapat disimpulkan memang terdapat keterbatasan mediator yang terdaftar di Pengadilan ini. ${ }^{27}$

\section{Kurangnya Iktikad Baik Para Pihak}

Itikad baik para pihak sangat penting guna keberhasilan proses mediasi agar tercapai kesepakatan yang win-win solution. Apabila para pihak tidak mau melihat kebutuhan mereka dan hanya mengejar keuntungan, maka perdamaian melalui mediasi sangat sulit untuk terwujud, dalam melaksanakan mediasi baik pihak penggugat maupun tergugat apabila menpuyai itikad baik untuk menyelesai

\footnotetext{
${ }^{25}$ Wawancara Dengan Taufik Abdul Halim Nainggolan Hakim Mediator Pengadilan Negeri Batam Pada Tanggal 4 April 2019.

${ }^{26}$ Wawancara Dengan Jasael, Hakim Mediator Pengadilan Negeri Batam Pada Tanggal 12 Februari 2019

${ }^{27}$ Wawancara dengan Asron Lubis Mediator Swasta Pada Tanggal 16 September 2019.
} 
perkara dalam pertemuan mediasi maka tingkat terjadi kesepakatan perdamian semakin tinggi. ${ }^{28}$

Berdasarkan hasil wawancara salah seorang Advokat di Pengadilan Negeri Batam menerangkan Tidak ada iktikad baik untuk melaksanakan mediasi merupakan suatu hambatan seperti hal yang ditemukan dalam praktek ada pihak yang dalam proses mediasi tidak hadir setelah dipanggil secara patut 2 (dua) kali berturut-turut dalam pertemuan Mediasi tanpa alasan sah, dan juga ada menghadiri pertemuan Mediasi pertama, tetapi tidak pernah hadir pada pertemuan berikutnya dan mediator harus memanggil kembali yang mengakibatkan jadwal pertemuan terganggu dan ada juga menghadiri pertemuan Mediasi, tetapi tidak mengajukan usulan ataupun tawaran untuk perdamaian dan juga tidak menanggapi tawaran atau usulan pihak lawan. ${ }^{29}$

3. Dalam Suatu Perkara Terlalu Banyak Pihak Dalam Gugatan Baik Penggugat Maupun Tergugat Sehingga Apabila Ada Salah Satu Pihak Maupun Beberapa Pihak Tidak Hadir Dalam Proses Mediasi Maka Mediator Harus Memanggil Kembali Sehingga Jadwal Mediasi Harus Tunda Ke Pertemuan Yang Berikutnya. Dan Tingkat Kesulitan Penyelesaian Sengketa Melalui Proses Mediasi Semakin Tinggi.

Berdasarkan hasil wawancara salah seorang hakim mediator Pengadilan Negeri Batam menerangkan jika pihak yang bersengketa terlalu banyak dalam gugatan, sehingga apabila ada salah satu pihak maupun beberapa pihak tidak hadir dalam proses mediasi, maka mediator harus memanggil kembali sehingga jadwal mediasi harus tunda ke pertemuan yang berikutnya pada umumnya membutuhkan waktu satu minggu. Dan juga untuk pihaknya terlalu banyak dalam suatu gugatan maka masing-masing mempuyai kepentingan yang berbeda, dan untuk tawaran masing-masing juga tidak sama sehinga tingkat kesulitan penyelesaian sengketa melalui proses mediasi semakin tinggi. ${ }^{30}$

\section{E. Kesimpulan}

Adapun kesimpulan Dari hasil penelitian yang telah dilakukan melalui wawancara dan pengamatan langsung di Pengadilan Negeri Batam, maka diperoleh kesimpulan terhadap rumusan masalah dalam penelitian ini, yaitu :

1. Mediasi di Pengadilan Negeri Batam belum berjalan efektif dengan faktor-faktor penyebabnya adalah sebagai berikut :

a. Sarana dan Fasilitas b. Faktor Masyarakat c. Faktor Kebudayaan

2. Peraturan Makahmah Agung nomor 1 Tahun 2016 Tentang Prosedur Mediasi Di Pengadilan mempunyai kekuatan hukum mengikat.

\footnotetext{
${ }^{28}$ Nurnaningsih Amriani, Mediasi Alternatif Penyelesaian Sengketa Perdata Di Pengadilan, Jakarta: Rajawali Pers, 2012, hlm. 156-157.

${ }^{29}$ Wawancara dengan Rudianto, tanggal 12 Maret 2019 di Pengadilan Negeri Batam.

${ }^{30}$ Wawancara Dengan Taufik Abdul Halim Nainggolan Hakim Mediator Pengadilan Negeri

Batam Pada Tanggal 4 April 2019.
} 
3. Faktor dan hambatan yang dihadapi dalam pelaksanaan proses mediasi di Pengadilan Negeri Batam sebagai berikut:

1. Keterbatasan jumlah mediator yang terdaftar di Pengadilan Negeri Batam.

2. Kurangnya Iktikad Baik Para Pihak.

3. Dalam suatu perkara terlalu banyak pihak dalam gugatan. 


\section{DAFTAR PUSTAKA}

\section{Buku}

H.M. Fauzan, Peranan PERMA \& SEMA Sebagai Pengisi Kekosongan Hukum Indonesia Menuju Terwujudnya Peradilan Yang Agung, Jakarta: Kencana Prenadamedia Group, 2013.

Maskur Hidayat, Strategi \& Taktik Mediasi Berdasarkan Perma No. 1 Tahun 2016 Tentang Prosedur Mediasi Di Pengadilan, Jakarta: Kencana, 2016.

Moh. Nazir, Metode Penelitian, Bogor: Ghalia Indonesia, 2011.

M. Karjadi, Reglemen Indonesia Yang Dibaharui S. 1941 No. 4, Bogor, Politeai Bogor, 1985.

Nurnaningsih Amriani, Mediasi Alternatif Penyelesaian Sengketa Perdata Di Pengadilan, Jakarta: Rajawali Pers, 2012.

R. Soesilo, RIB/HIR Dengan Penjelasan, Politeai Bogor: Sinar Grafika, 1985.

Soerjono Soekanto, Faktor-Faktor yang Mempengaruhi Penegak Hukum, Cetakan Ke13, Jakarta: PT. Rajagrafindo Persada, 2014.

Soerjono Soekanto, Sri Mamudji, Penelitian Hukum Normatif Suatu Tinjauan Singkat, Cetakan ke-17, Jakarta: Rajawali Pers, 2015.

Sugiyono, Metode Penelitian Kuantitatif Kualitatif Dan $R \& D$, Bandung: Alfabeta, 2013.

Syahruddin Nawi, Penelitian Hukum Normatif Versus Penelitian Hukum Empiris, Makasar: Umitoha, 2018.

\section{Internet}

https://idtesis.com/metode-penelitian-hukum-empiris-dan-normatif/

\section{Peraturan Perundang-undangan}

Undang-undang Republik Indonesia Nomor 14 Tahun 1985 Tentang Mahkamah Agung.

Undang-undang Republik Indonesia Nomor 5 Tahun 2004 Tentang Perubahan atas undang-undang Nomor 14 Tahun 1985 Tentang Mahkamah Agung.

Undang-undang Republik Indonesia Nomor 3 Tahun 2009 Tentang Perubahan Kedua atas Undang-undang Nomor 14 Tahun 1985 tentang Mahkamah Agung.

Peraturan Mahkamah Agung Nomor 1 Tahun 2016 Tentang Prosedur Mediasi Di Pengadilan. 